JOURNAL ARTICLE - RESEARCH INSTITUTE FOR SPECIAL AND INCLUSIVE EDUCATION

\title{
THE LEARNING AUTONOMY OF THE VISUALLY IMPAIRED STUDENTS
}

\author{
Cunhat Hiago* and Teera Sade \\ Research Institute for Special and Inclusive Education \\ *Corresponding author's email: cunhathiago@gmail.com
}

\begin{abstract}
After a definition of learning autonomy which emphasizes its relative nature, the reflection revolves around two questions: what are the obstacles to the autonomy of visually impaired students, in general and more particularly in language education and language acquisition, and what can be done for the students to grow? The capacities of each student, his/her personal and social attitude, the situations he/she is confronted with, the margin of freedom or independence which is granted or which he/she agrees with, the attitude of those around him/her, and the teacher's skills appear to be determining factors for optimal autonomy in language education and language acquisition. The article continues with the presentation of teaching procedures aimed at making the student more independent. The discussion also describes the limits of the attention currently paid to learning autonomy in various countries.
\end{abstract}

Keywords: language education, language acquisition, visual impairment, learning autonomy, attitude. 


\section{$\underline{\text { FULL TEXT }}$}

\section{APA CITATION:}

Hiago, C., \& Sade, T. (2020). The learning autonomy of the visually impaired students in language education and language acquisition. Journal of Special and Inclusive Education, 13(1), 27-49.

\section{Disclosure statement}

No potential conflict of interest was reported by the authors.

\section{REFERENCES}

Agesa, L. (2014). Challenges faced by learners with visual impairments in inclusive setting in Trans-Nzoia County. Journal of Education and Practice, 5(29), 185-192.

Archibald, M. M. (2015). Investigator triangulation: A collaborative strategy with potential for mixed methods research. Journal of Mixed Methods Research, 10(3), 228-250.

Arslantaş, T. K. (2017). Foreign language education of visually impaired individuals: A review of pervasive studies. IHEAD: Ihlara Journal of Educational Research, 2(2), 95-104.

Atkinson, P., \& Hammersley, M. (1998). Ethnography and participant observation. In N. K. Denzin \& Y. S. Lincoln (Eds.), Strategies of qualitative inquiry (pp. 110-136). Thousand Oaks, CA: Sage. 
Birchler, K., \& Michaelow, K. (2016). Making aid work for education in developing countries: An analysis of aid effectiveness for primary education coverage and quality. International Journal of Educational Development, 48, 37-52.

Bolt, D. (2005). From blindness to visual impairment: Terminological typology and the social model of disability. Disability \& Society, 20, 539-552.

Burns, D. (2018). Deepening and scaling participatory research with the poorest and most marginalised. European Journal of Operational Research, 268(3), 865-874.

Casper, M. J., \& Talley, H. L. (2005). Preface: Ethnography and disability studies. Journal of Contemporary Ethnography, 34(2), 115-120.

Danforth, D., \& Gabel, S. L. (2006). Vital questions facing disability studies in education. New York, NY: Peter Lang.

Davis, L. J. (2002). Bending over backwards: Disability, dismodernism, and other difficult positions. New York, NY: New York University Press.

Denzin, N. K. (2006). Sociological methods: A sourcebook. Piscataway, NJ: Transaction Publishers. DePoy, E., \& Gilson, S. F. (2011). Studying disability: Multiple theories and responses. Thousand Oaks, CA: Sage.

Eckes, A., Großmann, N., \& Wilde, M. (2018). Studies on the effects of structure in the context of autonomy-supportive or controlling teacher behavior on students' intrinsic motivation. Learning and Individual Differences, 62, 69-78.

Florian, L. (2008). Special or inclusive education: Future trends. British Journal of Special Education, 35(4), 202-208. 
Gabel, S. L. (2005). Disability studies in education: Readings in theory and method. New York, NY: Peter Lang.

Goldstein, D. (2000). Music pedagogy for the blind. International Journal of Music Education, 35, 35-39.

Hersh, M. A., \& Johnson, M. A. (2008). Disability and assistive technology systems. In M. A. Hersh \& M. A. Johnson (Eds.), Assistive technology for visually impaired and blind people (pp. 1-50). London: Springer.

Jenks, E. B. (2005). Parents' stories of raising children with visual impairments in a sighted world. Journal of Contemporary Ethnography, 34, 143-169.

Jones, C. B., Isham, L., \& Taylor, J. (2018). The complexities and contradictions in participatory research with vulnerable children and young people: A qualitative systematic review. Social Science \& Medicine, 215, 80-91.

Masino, S., \& Zarazúa, M. N. (2016). What works to improve the quality of student learning in developing countries? International Journal of Educational Development, 48, 53-65.

Melie, S., William, G., Susanto, S., \& Nanda, D. S. (2020). Foreign language training for visually impaired students in South East Asian countries. https://doi.org/10.31219/osf.io/vjrng.

Nanda, D. S. (2016, May). Fostering the Use of Drama for English Language Learners in the Efl Classroom. In International Conference on Education and Language (ICEL) (p. 7).

Nugent, M. (2018). Reframing inclusion: An exclusive-inclusive approach. British Journal of Special Education, 45(2), 141-156. 
Puri, I. R., Rodiatun, R., \& Susanto, S. (2019). An Analysis of Learnıng English Vocabulary for Hearıng Impaired Student at Dharma Bhakti Dharma Pertiwi Special School 2017/2018. Journal of English Education Studies, 2(1), 60-66.

Reason, P. (1998). Three approaches to participatory inquiry. In N. K. Denzin \& Y. S. Lincoln (Eds.), Strategies of qualitative inquiry (pp. 324-338). Thousand Oaks, CA: Sage.

Savage, J. (2013). Participative observation: Standing in the shoes of others. Qualitative Health Research, 10(3), 324-339.

Siebers, T. (2006). Disability theory. Ann Arbor, MI: University of Michigan Press.

Stake, P. (2005). Qualitative case study. In N. K. Denzin \& Y. S. Lincoln (Eds.), The sage handbook of qualitative research (pp. 433-466). New York, NY: Sage.

Susanto, S. (2016). A case study of prosodic phrasal grouping and intonational prominence in language acquisition. English Review: Journal of English Education, 4(2), 289-295.

Susanto, S., \& Nanda, D. S. (2018). Teaching and learning English for visually impaired students: an ethnographic case study. English Review: Journal of English Education, 7(1), 83-92.

Thompson, R. G. (1997). Extraordinary bodies: Figuring physical disability in American culture and literature. New York, NY: Columbia University Press.

Weber, A., Braun, B., \& Crocker, M. W. (2006). Finding referents in time: Eye-tracking evidence for the role of contrastive accents. Language and Speech, 49(3), 367-92.

Whitburn, B. (2014). Accessibility and autonomy preconditions to 'our' inclusion: A grounded theory study of the experiences of secondary students with vision impairment. Journal of Research in Special Educational Needs, 14(1), 3-15. 
Zhou, M. (2016). The roles of social anxiety, autonomy, and learning orientation in second language learning: A structural equation modeling analysis. System, 63, 89-100. 